\title{
EFEKTIVITAS PSEUDOMONAS FLUORESCENS TERHADAP PENYAKIT LAYU BAKTERI (RALSTONIA SOLANACEARUM) PADA TANAMAN KACANG TANAH
}

\author{
Yadi Suryadi $^{1}$
}

\begin{abstract}
Effectiveness of Pseudomonas fluorescens against groundnut bacterial wilt (Ralstonia solanacearum). The experiment was conducted to study effectiveness of Pseudomonas fluorescens $(P F)$ soil drenching application against groundnut bacterial wilt disease (Ralstonia solanacearum) suppression. Results showed that $P F$ applications gave significant effect to reduce wilt incidence. The lowest wilt incidence $(7.17 \%)$ was obtained by three times periodically soil drenching of the growing plant ( 1 day before planting, 15 days after planting and 30 days after planting) with $P F\left(10^{7} \mathrm{cfu} / \mathrm{ml}\right)$ suspensions. $P F$ applications showed no significant effect on plant height which ranging from $13,07 \mathrm{~cm}-15,60 \mathrm{~cm}$. In addition, $P F$ applications showed wet root and pod weight ranging from $0,35 \mathrm{~g}-0,83 \mathrm{~g}$ and $7,13 \mathrm{~g}-9,13 \mathrm{~g}$, respectively which significantly different compared with untreated $P F$ application.
\end{abstract}

Key words: Pseudomonas fluorescens, Ralstonia solanacearum, groundnut wilt

\section{PENDAHULUAN}

Penyakit layu bakteri (PLB) yang disebabkan oleh Ralstonia solanacearum (RS) (Yabuuchi et al., 1995) merupakan salah satu penyakit utama tanaman kacang tanah yang tersebar luas di daerah tropis maupun subtropis. Di Indonesia PLB tersebar meliputi daerah pertanaman kacang tanah di Sumatera Utara, Sumatera Barat, Lampung, Jawa Barat, Jawa Tengah, Jawa Timur, Bali dan Sulawesi Selatan (Machmud, 1986). Bakteri $R S$ memiliki kisaran inang yang luas dan menginfeksi lebih dari 33 famili termasuk tanaman budidaya dan tanaman inang lainnya seperti Croton hirtus, Crassocephalum crepidioides, Ocsimum basilicum, Sesbania rostrata, dan Crotalaria spp., selain itu juga $R S$ dilaporkan dapat menginfeksi secara laten (latent of infection) dan dapat berkembang biak pada tanaman tanpa menimbulkan gejala layu (Machmud \& Hayward, 1992).

Pengendalian PLB dapat dilakukan secara terpadu melalui upaya kultur teknis antara lain dengan penggunaan varietas tahan dan pergiliran tanaman (Mahmud et al., 1996). Penggunaan pestisida untuk menekan PLB dilaporkan efektif, namun selain mahal cara ini dapat menimbulkan masalah pencemaran lingkungan. Oleh karena itu perlu dicari alternatif pengendalian lain yang murah dan efektif dalam menekan $R S$.
Pengendalian penyakit, selain menggunakan varietas tahan dan bakterisida, pengendalian hayati menggunakan mikroorganisme antagonis $P F$ telah dilaporkan efektif oleh beberapa peneliti terhadap penekanan penyakit layu pada tanaman pisang dan krisan, yang disebabkan oleh Fusarium oxysporum (Djatnika, 1998), dan terhadap PLB yang disebabkan $R S$ pada tanaman tomat serta tanaman kentang (Mulya, 1997; Aspiras \& Angela, 1986).

Agensia pengendali hayati umumnya lebih efektif bila diaplikasikan sebagai perlakuan preventif sebelum penyakit berkembang dan aplikasi lanjutan perlu dilakukan untuk memperoleh penekanan penyakit yang dapat bertahan lama (Utkhede, 2005), namun keefektifan agensia pengendali hayati antara lain dapat dipengaruhi pula oleh faktor-faktor lingkungan, baik biotik maupun abiotik (Someya et al., 2005). Gnanamanickam et al., (2004) mengemukakan bahwa waktu aplikasi serta banyaknya aplikasi $P F$ sangat berpengaruh terhadap penekanan intensitas serangan penyakit hawar daun bakteri (HDB) pada tanaman padi. Pada tanaman padi, 3 kali aplikasi agensia hayati yang disemprotkan pada permukaan daun padi sejak umur 14 hari setelah tanam (HST), 28 HST dan 42 HST dapat mengurangi laju infeksi penyakit HDB (Baskoro, komunikasi pribadi).

\footnotetext{
${ }^{1}$ Laboratorium Bakteriologi Departemen Biokimia, Balai Besar Penelitian dan Pengembangan Bioteknologi dan Sumber Daya Genetik Pertanian (BB-Biogen), J1n. Tentara Pelajar 3A, Bogor 16111 Tel. 0251-8337975, Fax. 0251-8338820
} 
Upaya pencarian agensia hayati untuk mengendalikan patogen $R S$ telah dilaporkan dengan hasil yang masih bervariasi dalam hal efektivitasnya, oleh karena itu perlu dicari upaya terbaik agar aplikasi agensia hayati dapat meningkat efektivitasnya dalam mengendalikan PLB di lapangan. Berdasarkan hal tersebut di atas aplikasi agensia hayati $P F$ dalam menekan PLB perlu dikaji lebih lanjut dan makalah ini melaporkan efektivitas $P F$ hasil isolasi dari rhizosfera tanaman kacang tanah yang efektif dalam menekan infeksi PLB pada tanaman kacang tanah.

\section{METODE PENELITIAN}

Penelitian dilakukan pada bulan Juni sampai dengan Desember 2006, di laboratorium dan rumah kaca (RK) BB Biogen Bogor. Isolat $R S$ dan $P F$ masing-masing diperoleh dari pertanaman tanaman kacang tanah yang menunjukkan gejala PLB, dan sampel tanah di sekitar bekas pertanaman kacang tanah (rhizosfera) dari daerah Karadenan, Kecamatan Cibinong- Bogor.

Isolasi bakteri $\boldsymbol{P F}$ dan $\boldsymbol{R S}$. Tanaman kacang tanah terinfeksi layu bakteri dicuci dengan air mengalir. Dari bagian pangkal batang yang terlihat berwarna kuning kecoklatan dipotong miring dan didesinfektasi dengan alkohol $70 \%$ selama \pm 3 menit, kemudian dimasukkan ke dalam tabung reaksi yang telah berisi $15 \mathrm{ml}$ aquades steril. Suspensi bakteri dipindahkan dengan menggunakan ose ke permukaan medium Sucrose Peptone Agar (SPA) pada cawan petri dan diinkubasikan selama 24 jam pada kondisi suhu kamar

Pemurnian koloni bakteri $R S$ dilakukan dengan cara memindahkan beberapa kali kultur bakteri $R S$ pada medium Trifenil tetrazolium klorida (TZC) dan diinkubasikan selama 3 hari pada suhu ruang. Identifikasi isolat $R S$ dilanjutkan dengan uji reaksi gram $(\mathrm{KOH})$ dan reaksi hipersensitivitas pada tanaman tembakau (Klement et al., 1990).

Isolasi $P F$ dilakukan dengan mengambil sebanyak 2 g sampel tanah, kemudian disuspensikan dengan $20 \mathrm{ml}$ air steril dalam tabung reaksi. Suspensi tersebut dikocok dengan menggunakan shaker hingga merata. Selanjutnya suspensi diencerkan dengan air pada tingkat pengenceran $10^{-1}$, kemudian ditumbuhkan pada media Agar King's $B$ yang ditambah antibiotik ampicilin (10 ppm) dan diinkubasikan pada suhu kamar selama 48 jam. Koloni $P F$ yang positif ditunjukkan dengan adanya pigmen mengkilap dan memantulkan pendar (fluoresensi) berwarna kehijauan apabila biakan dilihat di bawah sinar UV $(\lambda=266 \mathrm{~nm})$. Koloni $P F$ yang telah diperbanyak pada media agar miring kemudian ditumbuhkan dalam media SP (Sucrose Peptone) yang ditambah larutan $0,1 \mathrm{M} \mathrm{MgSO}_{4} \cdot 7 \mathrm{H}_{2} \mathrm{O}$ dengan masa inkubasi selama \pm 48 jam, dan kerapatannya diukur menggunakan spektrofotometer sehingga diperoleh kerapatan bakteri $10^{7} \mathrm{cfu} / \mathrm{ml}$.

\section{Uji antagonisme $P F$ terhadap $R S$ secara in vitro.} Pengujian antagonisme di laboratorium dilakukan terhadap isolat-isolat $P F$ yang telah diisolasi dari rhizosfer. Uji antagonisme antara $P F$ dan $R S$ dilakukan dengan cara menuangkan sebanyak $100 \mathrm{ml}$ suspensi $R S$ $\left(10^{7} \mathrm{cfu} / \mathrm{ml}\right)$ ke dalam cawan petri berisi media Agar $S P$. Selanjutnya potongan cakram kertas saring Whatman No. 2 berdiameter $1 \mathrm{~cm}$ dicelupkan ke dalam suspensi $P F\left(10^{7} \mathrm{cfu} / \mathrm{ml}\right)$ dan dikering anginkan sebentar, lalu diletakkan di tengah cawan petri berisi bakteri $R S$. Inkubasi dilakukan selama 72 jam kemudian diamati lebar zona bening di sekeliling $P F$. Setiap perlakuan diulang sebanyak lima kali. Luas zona hambatan dihitung dengan menggunakan rumus sebagai berikut :

Zona hambatan $=\frac{r 1+r 2}{2}$

dimana :

$\mathrm{r}_{1}=$ jari-jari pada zona bening yang terpanjang

$r_{2}=$ jari-jari pada zona bening yang terpendek

Aplikasi $P F$ terhadap $R S$ secara in vivo. Pengujian antagonisme secara in vivo di rumah kaca dilakukan dengan mengaplikasikan isolat $P F$ yang membentuk zona hambatan paling besar dari hasil uji in vitro. Persiapan media tanam berupa campuran tanah dengan pupuk kandang $(4: 1)$ yang telah disterilisasi dengan menggunakan fumigasi kloroform 20\%. Polybag berdiameter $30 \mathrm{~cm}$ berisi tanah dan pupuk kandang diberi perlakuan terlebih dahulu kemudian benih ditanam langsung pada polybag, masing-masing berisi 1 benih kacang tanah varietas Kelinci. Selanjutnya ke dalam media tanah diberi pupuk majemuk NPK $(1: 1: 1)$ sebanyak $3 \mathrm{~g} /$ polybag. Koloni $R S$ yang telah diperbanyak pada media agar miring selama 48 jam dipanen seluruhnya, kemudian ditumbuhkan dalam media cair $S P$ selama \pm 48 jam dan diukur kerapatannya sampai $10^{7} \mathrm{cfu} / \mathrm{ml}$. Media tanah disiram dengan $30 \mathrm{ml}$ filtrat suspensi $R S$ saat 2 hari sebelum tanam, kecuali perlakuan kontrol. Penelitian disusun dalam Rancangan Acak 
Lengkap (RAL) terdiri dari delapan perlakuan dan tiga ulangan.

Pengamatan tanaman kacang tanah yang terserang PLB dilakukan setiap minggu, dimulai sejak 7 HST hingga 70 HST. Intensitas PLB dihitung dengan menggunakan rumus sebagai berikut :

$$
I=\frac{n}{N} x 100 \%
$$

dimana :

$\mathrm{I}=$ persentase intensitas kejadian penyakit layu (\%) $\mathrm{n}=$ jumlah tanaman yang menunjukkan gejala layu $\mathrm{N}=$ total jumlah tanaman yang diamati

Peubah lain yang diamati antara lain : tinggi tanaman saat 30 HST, bobot basah akar dan polong tanaman saat panen. Analisis statistik dilakukan dengan ANOVA menggunakan program komputer IRRISTAT Version 92-1 (Biometrics Unit, International Rice Research Institute, Manila, Filipina) dan uji beda nyata pada taraf $5 \%$.

\section{HASIL DAN PEMBAHASAN}

Isolasi bakteri $R S$ dari tanah bekas pertanaman kacang tanah pada media TZC menghasilkan dua isolat bakteri $R S$ yaitu virulen dan avirulen. Setelah beberapa pengujian sifat fisik isolat $R S$ maka untuk meyakinkan dilakukan inokulasi suspensi bakteri $R S\left(10^{7} \mathrm{cfu} / \mathrm{ml}\right) \mathrm{ke}$ ketiak daun tanaman kacang tanah berumur 2 minggu sehingga timbul gejala layu pada hari ke 5 setelah inokulasi. Gejala awal adalah daun-daun menjadi layu seperti tersiram air panas, akhirnya daun-daun menjadi berwarna coklat dan mengering. Berdasarkan pengujianpengujian ini dipastikan bahwa isolat $R S$ adalah virulen. Pengujian reaksi gram dengan pemberian larutan $\mathrm{KOH}$ 3\% menunjukkan koloni bakteri berbentuk gel/lendir yang berarti bakteri tersebut merupakan bakteri gram negatif. Selanjutnya koloni bakteri $R S$ murni yang berumur 24 jam dengan konsentrasi $\pm 10^{8} \mathrm{cfu} / \mathrm{ml}$ disuntikkan ke bagian mesofil daun tembakau yang berumur 40 hari. Hasil uji hipersensitivitas pada daun tanaman tembakau tersebut menunjukkan gejala

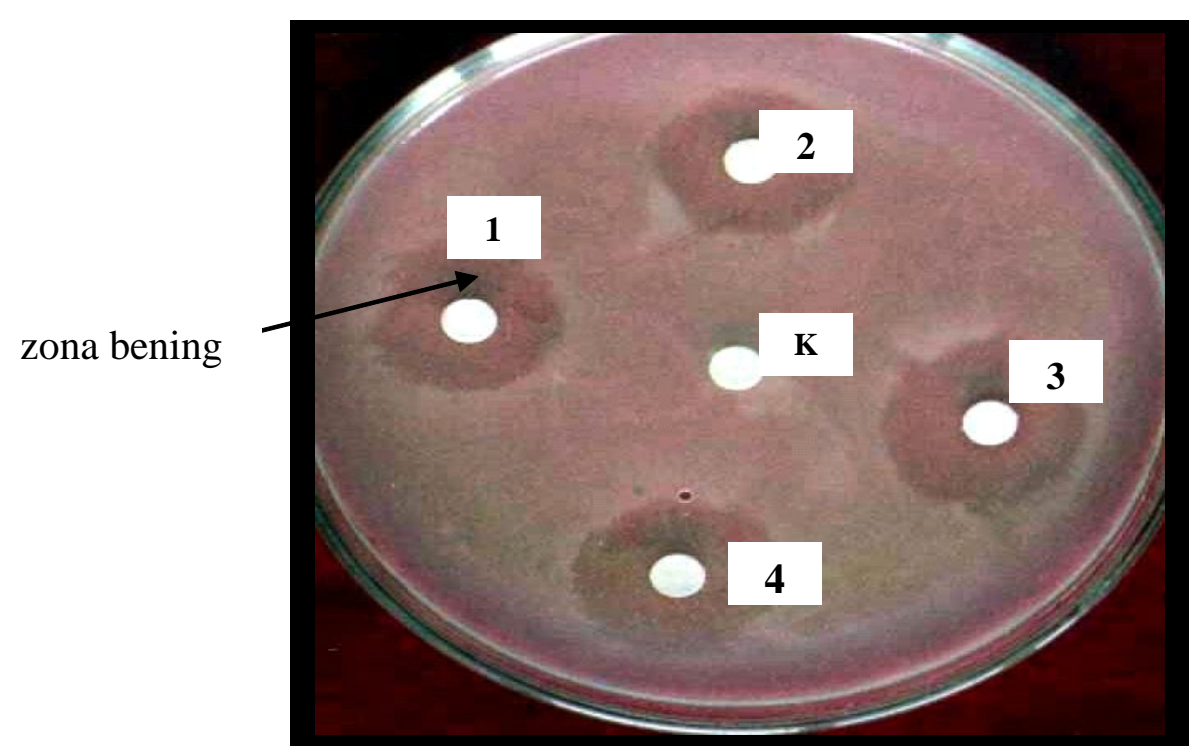

Gambar 1. Zona bening pada media SPA sebagai hasil lisis koloni $R S$ di sekeliling kertas cakram yang telah ditetesi suspensi $P F$ (no 1, 2, 3, dan 4). $\mathrm{K}=$ Kontrol negatif (buffer/air steril) 
nekrotik secara jelas pada daun yang telah diinokulasi, dimana terlihat adanya perubahan warna daun menjadi kuning kecoklatan dan daun menjadi kering 2 hari setelah inokulasi.

Uji antagonisme $P F$ terhadap $R S$ secara in vitro. Hasil isolasi bakteri $P F$ dari sampel rhizosfera tanaman kacang tanah diperoleh sembilan isolat $P F$. Isolat ini diperoleh dari hasil penapisan koloni-koloni bakteri pada media Agar King 's B yang memendarkan warna kuning kehijauan bila dilihat di bawah sinar UV. Hasil pengujian antagonisme bakteri $P F$ terhadap $R S$ secara in vitro memperlihatkan adanya zona bening di sekeliling kertas cakram yang telah direndam dalam $P F$ (Gambar 1).

Hasil penelitian memperlihatkan zona hambatan yang terbentuk mempunyai kisaran 0,4-6,9 cm (Tabel 1). Sebagian isolat menunjukkan zona hambatan cukup baik seperti isolat $P F 1, P F 2, P F 3, P F 4$ dan $P F$ 5; tetapi penghambatan tertinggi ditunjukkan oleh isolat $P F 3$ (> 3,5 cm) meskipun tidak berbeda nyata dibandingkan keempat isolat tersebut. Isolat $P F$ 6, $P F$ 7, $P F$ 8, dan $P F 9$ menunjukan penghambatan yang rendah dalam menekan $R S$ secara in vitro. Secara individual isolat-isolat $P F$ yang menunjukkan zona hambat tinggi diuji kembali, dimana isolat $P F 3$ paling konsisten dalam menekan $R S$ secara in vitro sehingga dipilih untuk digunakan dalam uji in vivo.

\section{Aplikasi $P F$ terhadap persentase tanaman layu dan pengaruhnya terhadap tinggi tanaman, bobot akar dan bobot polong}

Pengendalian penyakit oleh agensia hayati akan mengalami kegagalan jika patogen menginfeksi tanaman lebih dahulu dibandingkan dengan inokulasi agensia hayatinya (Someya et al., 2005). Aplikasi PF yang berpengaruh terhadap penekanan persentase kejadian PLB ditunjukkan pada Tabel 2.

Berdasarkan Tabel 2 terlihat penyiraman $P F$ pada tanah sebanyak tiga kali menggunakan isolat $P F 3$ dapat menekan PLB lebih efektif yang ditunjukkan dengan rendahnya kejadian persentase PLB dibanding kontrol. Hal ini didukung dengan hasil pengujian secara in vitro dimana $P F 3$ menghasilkan daya antibiosis tertinggi. Aplikasi $P F$ pada tanah yang diberikan 1 hari sebelum tanam dan aplikasi 2 kali penyiraman tanah masingmasing menunjukkan infeksi PLB 21,4\% dan 50,1\%. Perlakuan perendaman benih selama 15 menit menunjukkan efektivitas penekanan PLB sebesar 76,9\% dibanding kontrol. Menurut Mulya (1997), lama kolonisasi akar oleh bakteri antagonis merupakan salah

Tabel 1. Zona hambatan yang terbentuk dari hasil uji antagonisme $P F$ asal rhizosfera kacang tanah isolat Karadenan terhadap $R S$ secara in vitro

\begin{tabular}{cc}
\hline Isolat $P F$ & Zona hambatan $(\mathrm{cm})^{*}$ \\
\hline$P F .1$ & $6,8 \mathrm{c}$ \\
$P F .2$ & $5,8 \mathrm{bc}$ \\
$P F .3$ & $6,9 \mathrm{c}$ \\
$P F .4$ & $3,5 \mathrm{~b}$ \\
$P F .5$ & $3,9 \mathrm{bc}$ \\
$P F .6$ & $0,4 \mathrm{ab}$ \\
$P F .7$ & $1,1 \mathrm{ab}$ \\
$P F .8$ & $1,6 \mathrm{~b}$ \\
$P F .9$ & $0,9 \mathrm{ab}$ \\
Kontrol & $0,0 \mathrm{a}$ \\
\hline
\end{tabular}

Keterangan : Angka rata-rata yang di ikuti huruf yang sama menunjukkan tidak berbeda nyata menurut uji Scot Knot pada taraf 5\%. * data ditransformasi ke dalam $\sqrt{ } \mathrm{x}+0,5$ 
Tabel 2. Uji antagonisme $P F$ terhadap PLB secara in vivo (70 HST), serta pengaruhnya terhadap rerata tinggi tanaman (30 HST), hasil bobot basah akar, dan polong (saat panen)

\begin{tabular}{|c|c|c|c|c|c|}
\hline Aplikasi & $\begin{array}{c}\text { Rerata } \\
\text { persentase } \\
\text { tanaman layu } \\
(\%)\end{array}$ & $\begin{array}{c}\text { Efektivitas } \\
\text { dibanding } \\
\text { kontrol } \\
\text { tanpa } P F \\
(\%)^{* *} \\
\end{array}$ & $\begin{array}{l}\text { Rerata } \\
\text { tinggi } \\
\text { tanaman } \\
(\mathrm{cm})\end{array}$ & $\begin{array}{c}\text { Rerata } \\
\text { bobot } \\
\text { basah akar } \\
\quad(\mathrm{g})\end{array}$ & $\begin{array}{c}\text { Rerata } \\
\text { bobot } \\
\text { basah } \\
\text { polong } \\
(\mathrm{g}) \\
\end{array}$ \\
\hline $\begin{array}{l}\text { Perendaman benih selama } \\
15 \text { menit }\end{array}$ & 21,4 bc & 76,9 & $14,13 \mathrm{a}$ & $1,19 \mathrm{bc}$ & $21,33 \mathrm{~b}$ \\
\hline $\begin{array}{l}\text { Penyiraman tanah } 1 \text { hari } \\
\text { sebelum tanam }(1 \mathrm{x})\end{array}$ & $50,1 \mathrm{c}$ & 46,0 & 13,07 a & $1,54 \mathrm{c}$ & $20,87 \mathrm{~b}$ \\
\hline $\begin{array}{l}\text { Penyiraman tanah } 1 \text { hari } \\
\text { sebelum tanam }+15 \text { HST } \\
(2 \mathrm{x})\end{array}$ & $28,5 \mathrm{bc}$ & 69,3 & $13,80 \mathrm{a}$ & $1,44 \mathrm{c}$ & $20,73 \mathrm{~b}$ \\
\hline $\begin{array}{l}\text { Penyiraman tanah } 1 \text { hari } \\
\text { sebelum tanam }+30 \mathrm{HST} \\
(2 \mathrm{x})\end{array}$ & $21,4 \mathrm{bc}$ & 76,9 & $13,54 \mathrm{a}$ & $1,06 \mathrm{~b}$ & $19,33 \mathrm{~b}$ \\
\hline $\begin{array}{l}\text { Penyiraman tanah } 1 \text { hari } \\
\text { sebelum tanam }+15 \mathrm{HST}+ \\
30 \mathrm{HST}(3 \mathrm{x})\end{array}$ & $7,17 \mathrm{ab}$ & 92,3 & 15,60 a & $1,23 \mathrm{bc}$ & $19,40 \mathrm{~b}$ \\
\hline $\begin{array}{l}\text { Kontrol tanpa penyiraman } \\
P F \text { (hanya di beri } R S \text { ) }\end{array}$ & $92,8 \mathrm{~d}$ & - & 14,39 a & $0,71 \mathrm{a}$ & $12,20 \mathrm{a}$ \\
\hline $\begin{array}{l}\text { Kontrol tanpa penyiraman } \\
R S \text { (hanya di beri } P F \text { ) }\end{array}$ & $0,00 \mathrm{a}$ & - & $14,04 \mathrm{a}$ & $0,99 a b$ & $19,93 \mathrm{~b}$ \\
\hline $\begin{array}{l}\text { Kontrol tanaman sehat } \\
(\text { tanpa } R S \text { dan } P F)\end{array}$ & $0,00 \mathrm{a}$ & - & $14,80 \mathrm{a}$ & $0,94 \mathrm{ab}$ & $18,73 \mathrm{~b}$ \\
\hline
\end{tabular}

Keterangan : Angka rata-rata pada lajur yang diikuti huruf yang sama, menunjukkan tidak berbeda nyata menurut DMRT pada taraf 5\%.

** Efektivitas penurunan intensitas penyakit dibanding kontrol tanpa $P F(\%)$ dihitung menurut rumus:

$$
\mathrm{E}=100-\underset{\text { Intensitas kontrol tanpa } P F}{[\text { Intensitas pada perlakuan }} \times 100 \%]
$$

satu aspek penting dalam menentukan aktivitas melindungi daerah perakaran. $P F$ mempunyai kelebihan yaitu dapat menjadi pengkolonisasi primer bagi akar tanaman, sehingga dengan adanya kolonisasi akar oleh $P F$ dalam waktu yang cukup lama, maka $R S$ tidak dapat melakukan penetrasi ke dalam tanaman (Schippers et al., 1987).

Berdasarkan hasil penelitian ini terlihat bahwa efektifitas penghambatan kejadian PLB yang terbaik berturut-turut diperoleh penyiraman $P F$ sebanyak 3 kali (1 hari sebelum tanam, 15 HST dan 30 HST) yaitu sebesar 92,3\% dibandingkan kontrol tanpa $P F$, diikuti oleh penyiraman $P F$ sebanyak 2 kali (1 hari sebelum tanam dan 15 HST) dengan efektifitas sebesar 76,9\%, dan penyiraman $P F$ sebanyak 2 kali (1 hari sebelum tanam dan 30 HST) dengan efektivitas sebesar $69,3 \%$ (Tabel 2). Menurut Djatnika (1998), proses kolonisasi
$P F$ pada tanaman krisan terjadi antara umur 15-20 hari setelah diinfestasikan ke dalam media tumbuh. Populasi $P F$ pada tanaman krisan setelah umur 20-40 hari relatif tetap dan selanjutnya menurun setelah lebih dari 40 hari. Adanya perbedaan waktu penyiraman suspensi $P F$, akan berpengaruh terhadap jumlah kolonisasi populasi $P F \mathrm{di}$ dalam tanah. Suspensi $P F\left(10^{7} \mathrm{cfu} / \mathrm{ml}\right)$ dilaporkan juga dapat menekan pertumbuhan Fusarium oxysporum lebih efektif jika diaplikasikan pada tanaman krisan sebanyak 3 kali, yaitu saat 1 hari sebelum tanam, 15 HST dan 30 HST (Djatnika, 1998), sedangkan perendaman akar bibit tembakau dengan suspensi $P F\left(10^{7} \mathrm{cfu} / \mathrm{ml}\right)$ selama 30 menit dapat menekan $R S$ hingga 55\% (Maskuri et al., 2000). Pada penelitian ini penyiraman $P F$ pada kacang tanah hanya dilakukan sampai 30 HST, karena tanaman telah memasuki fase generatif, dimana ketahanan tanaman terhadap $R S$ pada fase ini semakin meningkat. 
Saat tanaman kacang tanah telah memasuki umur 30 HST, unsur hara yang di dapatkan tanaman diduga lebih terkonsentrasi untuk pembentukan ginofor. Berdasarkan hasil penelitian ini tinggi tanaman kacang tanah saat 30 HST pada semua aplikasi $P F$ menunjukkan pengaruh yang tidak berbeda nyata yaitu dengan kisaran tinggi tanaman 13,07-15,60 cm. Hal ini sedikit berbeda dengan hasil penelitian Djatnika (1998) dimana selain dapat menghambat perkembangan jamur patogen, $P F$ juga dilaporkan dapat memacu pertumbuhan tinggi tanaman krisan.

Pengamatan terhadap hasil bobot basah akar menunjukkan bahwa perlakuan penyiraman $P F$ berbeda dengan perlakuan tanpa $P F$, yang ditunjukkan dengan bobot basah akar berkisar dari 1,06-1,54 g. Aplikasi $P F$ sebanyak 1 kali (1 hari sebelum tanam) dan aplikasi $P F$ sebanyak 2 kali (1 hari sebelum tanam dan 15 HST) menunjukkan perbedaan hasil bobot basah akar masingmasing sebanyak $0,38 \mathrm{~g}$ dan $0,48 \mathrm{~g}$ dibanding perlakuan $P F$ sebanyak 2 kali (1 hari sebelum tanam dan 30 HST). Kondisi optimal bagi pertumbuhan tanaman kacang tanah dimungkinkan karena selain $R S$ tidak dapat melakukan penetrasi ke tanaman karena perakaran sudah dikolonisasi oleh $P F$, proses pembentukan polong di bagian akar juga akan menjadi lebih optimal. Rerata berat basah polong kacang tanah tertinggi $(21,33 \mathrm{~g})$ ditunjukkan oleh perlakuan perendaman benih dengan $P F$ selama 15 menit, hal ini mungkin disebabkan karena $P F$ lebih lama terkonsentrasi di sekitar akar terutama sejak benih mulai berkecambah, sehingga tanaman yang diberi tambahan $P F$ akan menghasilkan kadar unsur hara yang lebih banyak hingga fase pembungaan dan pembentukan polong.

Hasil penelitian menunjukkan bobot basah polong kacang tanah tertinggi $(20,87 \mathrm{~g})$ ditunjukkan oleh perlakuan aplikasi $P F 1$ kali (1 hari sebelum tanam). Aplikasi $P F$ menunjukkan bobot basah akar dan polong, masing-masing dengan kisaran 0,35-0,83 g dan kisaran $7,13-9,13 \mathrm{~g}$, yang berbeda nyata dibandingkan tanpa perlakuan $P F$.

Efisiensi dan konsistensi pengendalian hayati sangat tergantung pada aktifitas, densitas dan lokalisasi agensia hayati (Duijff et al., 1997). Widodo et al., (1993), menyatakan bahwa dengan perendaman benih, permukaan perakaran yang merupakan titik awal infeksi akan di dominasi oleh $P F$, sehingga $P F$ lebih mudah bersaing dengan patogen dalam pemanfaatan eksudat akar. Penelitian masih perlu dilakukan terhadap pengaruh sinergisme antara $P F$ yang terbukti efektif dalam menekan bakteri $R S$ dengan agensia hayati lainnya, serta faktor-faktor yang berperan dalam menekan laju infeksi PLB. Penelitian mengenai hal tersebut sedang dikaji lebih lanjut.

\section{SIMPULAN}

Berdasarkan hasil penelitian ini dapat disimpulkan :

1. Pada pengujian in vitro, aplikasi isolat $P F$ menunjukkan kisaran zona hambatan patogen $R S$ dengan kisaran 0,4-6,9 $\mathrm{cm}$ dengan rerata zona hambat tertinggi secara individual ditunjukkan oleh isolat $P F 3$.

2. Penyiraman secara berkala sebanyak 3 kali ( 1 hari sebelum tanam, 15 HST, dan 30 HST) dengan suspensi isolat $P F 3\left(10^{7} \mathrm{cfu} / \mathrm{ml}\right)$ memberikan persentase layu pada kacang tanah terkecil yaitu $7,17 \%$.

3. Aplikasi $P F$ menunjukkan pengaruh yang tidak berbeda terhadap tinggi tanaman dengan kisaran tinggi tanaman $13,07-5,60 \mathrm{~cm}$. Sementara itu aplikasi $P F$ menunjukkan bobot basah akar dan bobot basah polong masing-masing dengan kisaran $0,35-0,83 \mathrm{~g}$ dan kisaran 7,13-9,13 g, yang berbeda nyata dibandingkan tanpa perlakuan $P F$.

\section{SANWACANA}

Diucapkan terima kasih kepada Sdr. Y. Habibi dan E. Windiyati S.Si. atas pengumpulan isolat $R S$ dan $P F$, serta kepada Sdr. A. Anastasya sehingga penelitian ini dapat terlaksana.

\section{DAFTAR PUSTAKA}

Aspiras, R.B. \& R.C. Angela. 1986. Biocontrol of bacterial wilt in tomato and potato through preemptive colonization using Bacillus polymoxa Fu6 and P. fluorescens. Phillip. J. Crop. Sci. 11(1) : 1-4.

Djatnika, I. 1998. Pengaruh Pseudomonas fluorescens Migula terhadap patogenisitas Fusarium oxysporum Schelt pada tanaman krisan. Jurnal Hortikultura 8 (1) : 1014-1020.

Duijff, B.J., V. Gianinazzi-Pearson, \& P. Lemanceau. 1997. Involvement of the outermembrane lipopolysacharides in the endophytic root colonization of tomato roots by biocontrol Pseudomonas fluorescens strain WCS417r. The New Phytologist 135 : 325-334. 
Gnanamanickam, P. Vasudevan, \& Velusamy. 2004. Biological Control of bacterial Blight of rice in India with Rice-assosiated Bacteria : Insight into mechanism. Centre for advanced studies in Botany. University of Madras-Guindy campus. Chennai. India (Abstract).

Klement, Z., K. Rudolph, \& D.C. Sand. 1990. Methods in Phytobacteriology. Akademiai Kiado Press, Budapest.

Machmud, M. 1986. Bacterial wilt in Indonesia. In Persley G. J. (ed). Bacterial wilt disease in Asia and the South Pacific. Proc International Workshop, PCARRD-ACIAR, Philippines. ACIAR Proceedings No. 13 : 32-34.

Machmud, M. \& A.C. Hayward. 1992. Genetic and cultural control of peanut bacterial wilt pp:19-25. In Wright, G.C. \& K.J. Middleton (eds). Peanut improvement - a case study in Indonesia. Proc. ACIAR No. 40, Canberra, Australia.

Machmud, M., S.A. Rais, \& Y. Suryadi. 1996. Strategi pengendalian penyakit layu bakteri guna menunjang upaya peningkatan produksi kacang tanah di Indonesia pp:363-371 dalam: Saleh (ed) Risalah Seminar Nasional Prospek Pengembangan Agribisnis kacang tanah di Indonesia. Balitkabi Malang, Edisi khusus No 7.

Maskuri, T. Arwiyanto, \& T. Martoredjo. 2000. Pengaruh medium pertumbuhan terhadap kemampuan bakteri antagonis dalam menekan penyakit layu bakteri tembakau. pp: 664-670. dalam: Soedarmono et al. (eds). Prosiding Kongres Nasional XV dan Seminar Ilmiah PFI, Purwokerto.

Mulya, K. 1997. Penekanan perkembangan penyakit layu bakteri tomat oleh Pseudomonas fluorescens PFG32. Jurnal Hortikultura 7 (2): 685-691.
Shcippers, B., B. Lugtenberg, \& P. J. Weisbeek. 1987. Interaction of deleterious and beneficial rhizosphere microorganisms and the effect of cropping practices. Annu. Rev. Phytopathol. 25 : 1376-1381.

Someya, N., K. Tsuchiya, \& K. Akutsu. 2005. Negative interactions between antagonistic microbes phytopathogens and epiphytic microbes in biological control of plant pathogens p: 25-29 In Proc. of the Asian Conference on emerging trends in plant-microbe interactions (Gnanamanickam et al. (Eds). Univ. of Madras Chennai, India.

Utkhede, R. 2005. Molecular approaches for diagnosis and biological control of diseases of green house crops. p:11-18. In Proc. of the Asian Conference on emerging trends in plant-microbe interactions (Gnanamanickam et al., (Eds). Univ. of Madras Chennai, India.

Widodo, M. S. Sinaga, I. Anas, \& M. Machmud. 1993. Penggunaan Pseudomonas spp. kelompok fluorescens untuk pengendalian penyakit akar gada (Plasmodiophora brassicae Wor) pada caisin (Brassica campestris L. var chinensis (Rupr) Olson). Buletin Hama dan Penyakit Tumbuhan (6) 2 : 94-105.

Yabuuchi, E., Y. Kosako, I. Yano, H. Hotta, \& Y. Nishiuchi. 1995. Transfer of two Burkholderia and an alcaligenes species to Ralstonia gen. novproposal of Ralstonia pickettii (Ralston, Palleroni, and Doudoroff, 1973) comb.nov, Ralstonia solanacearum (Smith, 1896) comb.nov and Ralstonia eutropha (Davis, 1969) comb. nov. J. Microbiol. Immunol. 39 (11) : 897-904. 